\title{
Surveillance of Rotavirus Diarrhea in Hasan Sadikin Hospital Bandung
}

\author{
Dwi Prasetyo, ${ }^{1}$ Iesje Martiza, ${ }^{1}$ Yati Soenarto ${ }^{2}$ \\ ${ }^{1}$ Department of Pediatrics, Medical Faculty of Universitas Padjadjaran, \\ Hasan Sadikin Hospital, Bandung \\ ${ }^{2}$ Department of Pediatrics, Medical Faculty of Gajah Mada University, \\ Sardjito Hospital, Yogyakarta
}

\begin{abstract}
The diarrhea morbidity in Indonesia has increased, however, all the reports had not been done carefully, so that accurate surveillance are essential for improving quality of morbidity data. To determine the prevalence and clinical manifestations of rotavirus diarrhea and to characterize the circulating rotavirus strains, children below 5 years old who were admitted to Hasan Sadikin Hospital, Bandung because of diarrhea, from January 2006 through March 2007 were enrolled in a surveillance study and had stool specimens tested for the presence of rotavirus using enzyme immunoassay (EIA). The strains of rotavirus were determined using reverse transcriptase-polymerase chain reaction (RT-PCR). Rotavirus were detected in 47.8\% analyzed samples (87/184), G and P-genotype of rotavirus were G[1] $(37.5 \%)$ and $\mathrm{P}[6](53.5 \%)$. Most subjects were males (56\%), 6-11 months of age (35\%). Most common clinical manifestations besides diarrhea were dehydration (72.7\%) and vomiting (50\%). Subjects with positive rotavirus more common had dehydration ( $72 \%$ vs $28 \%$ ) and vomiting (61\% vs $39 \%)$. In conclusion, vomiting and dehydration are the prominent clinical manifestations of diarrhea with positive rotavirus infection. G1 and P6 are the most common genotype of rotavirus. [MKB. 2010;42(4):155-60].
\end{abstract}

Key words: Clinical manifestations, diarrhea, genotype, prevalence, rotavirus

\section{Surveilans Diare Rotavirus di Rumah Sakit Hasan Sadikin Bandung}

\begin{abstract}
Abstrak
Morbiditas diare di Indonesia meningkat, tetapi semua laporan belum dilakukan secara cermat, sehingga surveilans yang akurat penting untuk memperbaiki kualitas data. Penelitian ini dilakukan untuk menentukan prevalensi dan manifestasi klinis diare rotavirus serta karakteristik strain rotavirus, anak usia di bawah 5 tahun yang dirawat karena diare di RS Hasan Sadikin, Bandung, dari Januari 2006 sampai Maret 2007, diikutsertakan dalam suatu penelitian surveilans dan spesimen fesesnya diperiksa untuk mendeteksi adanya rotavirus dengan menggunakan enzyme immunoassay (EIA). Strain rotavirus diperiksa dengan reverse transcriptase-polymerase chain reaction (RT-PCR). Rotavirus terdeteksi pada 47,8\% sampel analisis (87/184), genotipe-G dan P adalah G[1] (37,5\%) dan P[6] (53,5\%) dari strain. Kebanyakan subjek adalah laki-laki (56\%) usia 6-11 bulan (35\%). Manifestasi klinis terbanyak adalah dehidrasi $(72,7 \%)$ dan muntah (50\%). Subjek dengan rotavirus positif lebih sering mengalami dehidrasi $(72 \%$ vs $28 \%$ ) dan muntah (61\% vs 39\%). Simpulan, muntah dan dehidrasi adalah manifestasi klinis terbanyak pada diare dengan infeksi rotavirus. Genotipe G1 dan P6 merupakan genotipe rotavirus yang paling sering ditemukan. [MKB. 2010;42(4):155-60].
\end{abstract}

Kata kunci: Diare, genotipe, manifestasi klinis, prevalensi, rotavirus

Korespondensi: Dr. Dwi Prasetyo, dr., SpA(K), M.Kes, Bagian Ilmu Kesehatan Anak, Fakultas Kedokteran Universitas Padjadjaran, Rumah Sakit Hasan Sadikin, Bandung, jalan Pasteur 38, telepon (022) 2034953-55,

e-mail:d_pras2000@yahoo.com 


\section{Introduction}

Diarrhea is a public health problem among developing countries, including Indonesia. Morbidity and mortality of diarrhea is still high. Until the beginning of $1980 \mathrm{~s}$, diarrhea is the most common cause of death in children below 5 years old, causing death of about 4.6 millions children worldwide every year. Rotavirus is the main cause of diarrhea and severe dehydration in children in developed and developing countries.'

Rotavirus is the most important cause of severe childhood diarrhea: globally about 1 in 200 children born each year die because of rotavirus diarrhea, and approximately 1 in 100 children born in the United States each year are hospitalized. ${ }^{2}$ In Indonesia, from ten main diseases of inpatient in 2005, the most was diarrhea and gastroenteritis caused by certain infection (7.53\%). The death level of diarrhea in 2005 had increased comparing to the previous year, where CFR of diarrhea was $2.51 \%$ with 125 deaths from 5.051 cases. It was higher than CFR in 2004 that was $1.6 \%$ with 23 deaths from 1,436 cases.

However, the diarrhea mortality rates has decreased. Based on household survey, death related to diarrhea had been decreased from $40 \%$ in 1970 to $24.9 \%$ in $1980,16 \%$ in 1986 to $7.5 \%$ in 1992 from all death cases. Last survey between 1990 and 2001, diarrhea is the second most important killer of young children. ${ }^{4}$ The facts about oral rehydration therapy had implemented broadly in Indonesia could be one of the reasons. ${ }^{5}$

Although there is no increment in diarrheal mortality data, the diarrhea morbidity in Indonesia had been increased. However, all the reports of diarrhea morbidity had not been done carefully, so that household data or cross sectional survey was needed to determine diarrhea morbidity and improve the quality of morbidity data. ${ }^{6}$

The purpose of this study was to determine the prevalence and clinical manifestations of rotavirus diarrhea, and to characterize the circulating rotavirus strains in children below 5 years old who were hospitalized in Hasan Sadikin Hospital, Bandung.

\section{Methods}

The study data was obtained from pediatric wards in Hasan Sadikin Hospital, Bandung from January
2006 through March 2007. The samples were collected from all patients below 5 years old who were admitted to hospital with diarrhea. Subjects who fulfilled the criterias and willing to paricipate were included in this study. AIl data were obtained from medical chart review or with family interview (mother/caregiver) in hospital by trained assistants.

Stool specimens were collected by nurse during hospitalization, which must be collected as soon as the patient is admitted to the hospital, then stored in the refrigerator before it was transported to the laboratorium in temperature $-70^{\circ} \mathrm{C}$. The enzyme immunoassay/EIA was used to examine rotavirus infection. Rotavirus strains were determined using reverse transcriptasepolymerase chain reaction (RT-PCR).

Statistical analysis was conducted using SPSS version 13.00 (SPSS inc. Chicago-Illinois, USA) for windows. Categorical variables were assessed for statistical significance using $\mathrm{X}^{2}$ test.

\section{Results}

From January 2006 to March 2007, a total of 952 children $<5$ years old were admitted to Hasan Sadikin Hospital because of diarrhea. The highest diarrhea visit was on May 2006 (104 children), followed by January, July, and August 2006 (Figure 1).

There were 187 hospitalized children that were eligible for the study, and 184 faecal samples were analyzed to detect rotavirus. Overall, rotavirus was detected in $47 \%$ samples $(87 / 184)$. The highest number of rotavirus was detected on July 2006 followed by January $(15 \%)$ and June $2006(15 \%)$ as shown in Figure 2.

Most of subjects were male (56\%) in 6-11 months of age group (35\%) followed by $12-23$ months of age group (25.8\%). The highest rotavirus detection number was in male subjects $(51 \%)$ in 6-11 months age group (41) followed by $12-23$ months (33\%).

We plotted the total number of hospital admission each month for diarrhea due to rotavirus infection (Figure 3). Rotavirus-related hospital admission was occured year-round, but the large monthly variability in rates made it difficult to demonstrate a distinct seasonal trend.

The common clinical manifestations in this study other than diarrhea were dehydration 


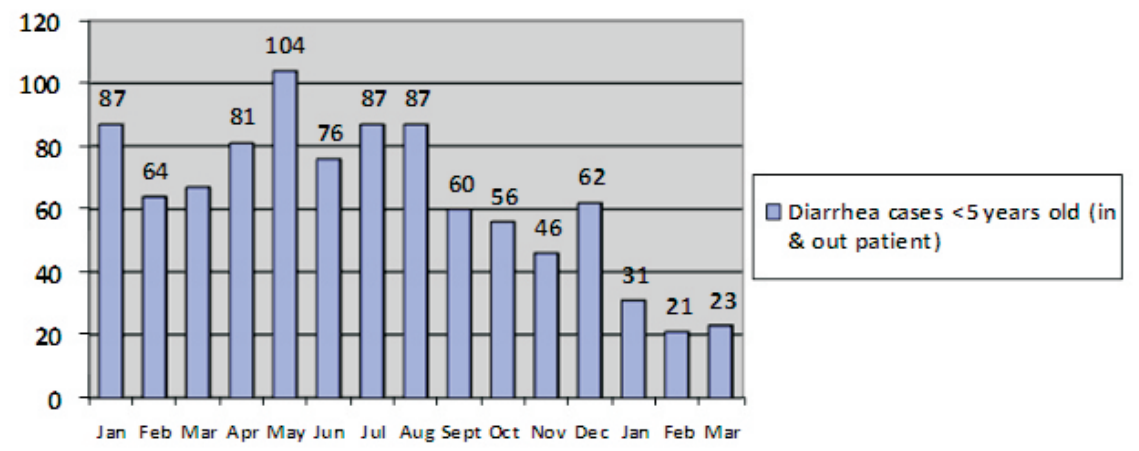

20062007

Figure 1 Diarrhea Cases in Children <5 Years Old Period January 2006 to March 2007

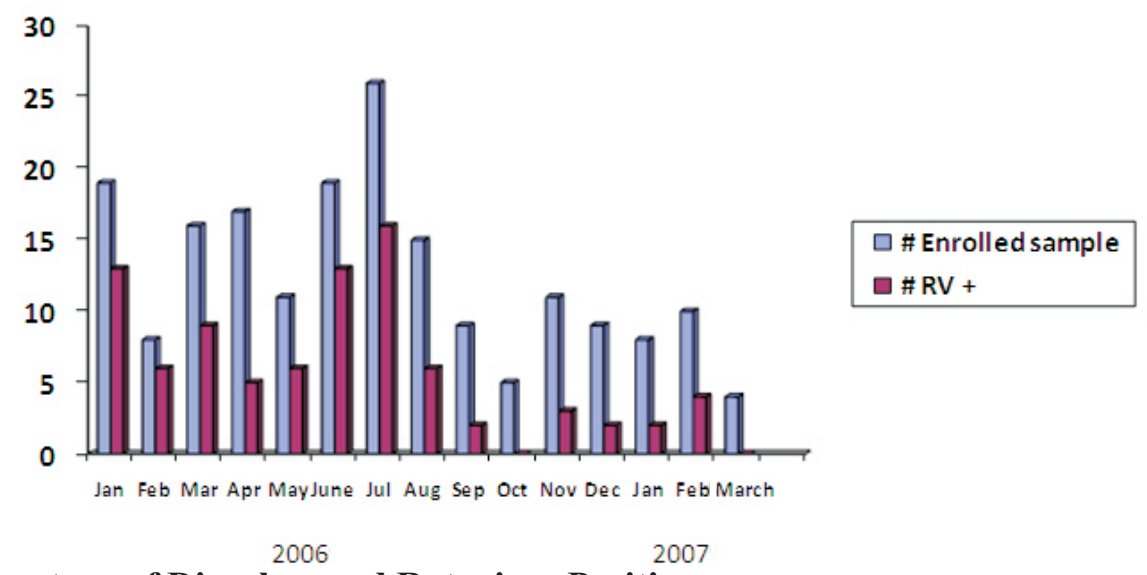

Figure 2 Percentage of Diarrhea and Rotavirus Positive

$(72.5 \%)$ and vomiting $(50 \%)$. Positive rotavirus subjects were more frequent to have dehydration $(70 \%$ vs $30 \%$; $<0.05)$ and vomiting $(61 \%$ vs $41 \%$ $; \mathrm{p}<0.05)$ compared with negative rotavirus,

Bloody diarrhea was only found in subject with negative rotavirus (4\%), although it is not different significantly. There was no significant difference in mucous stool between group with negative and positive rotavirus infection (29\% vs $51 \%$ ).
The most common G-genotype rotavirus causing diarrhea in children under 5 years of age in this study was G[1] (37.5\% of strains), followed by G[9] (25\%), G[2] (17.5\%) and nontypeable $(15 \%)$.

The most common P-genotype of rotavirus causing diarrhea in children under 5 years of age in this study was $\mathrm{P}[6]$ (53.5\% of strains), followed by nontypeable (22.5\%), P[4] (125\%), and mixed infection $(10 \%)$.

Table 1 Age Distribution of Patients with Rotavirus Positive Diarrhea

\begin{tabular}{|c|c|c|c|c|c|c|c|}
\hline Age group (Mo) & Enrolled (\%) & Tested & $\# \mathbf{R V}+(\%)$ & $\mathbf{X}^{2}$ & P value & OR & CI \\
\hline & & & & 14.4 & 0.006 & & \\
\hline $00-02$ & $20 \quad(11)$ & $20(11)$ & $8 \quad(9)$ & & & \multirow{2}{*}{$\begin{array}{l}2.5 \\
2.0\end{array}$} & $0.7-9.6$ \\
\hline $03-05$ & $29(16)$ & $29(16)$ & $10(12)$ & & & & $0.6-7.0$ \\
\hline $06-11$ & $65 \quad(35)$ & $64(35)$ & $35(40)$ & & & \multirow{2}{*}{$\begin{array}{l}4.6 \\
6.1\end{array}$} & $1.5-13.8$ \\
\hline $12-23$ & $49 \quad(26)$ & $47(26)$ & $29(33)$ & & & & $2.0-19.2$ \\
\hline$>23$ & $24 \quad(13)$ & $24(13)$ & $5(6)$ & & & 1 & - \\
\hline Total & $187(100)$ & 184 & $87(100)$ & & & & \\
\hline
\end{tabular}




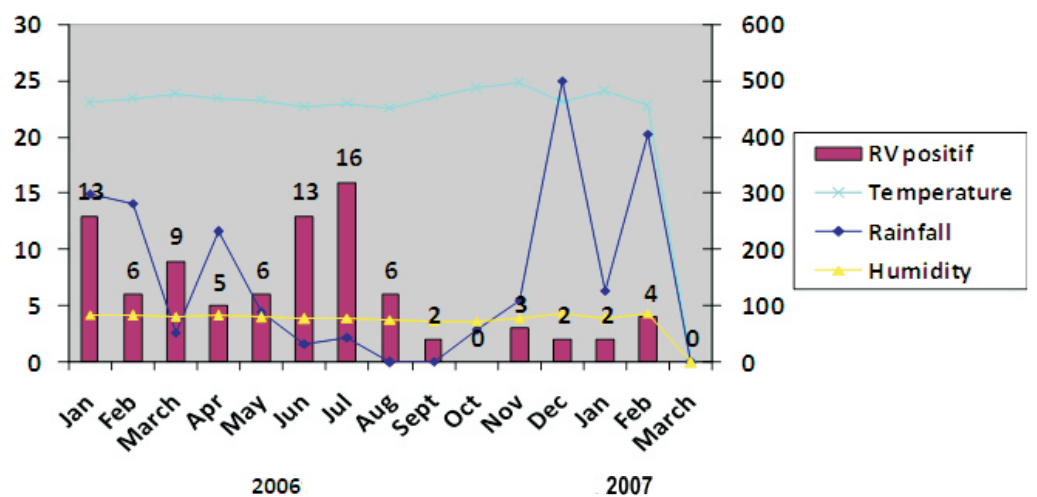

Figure 3 Rotavirus Positive Based on Seasonal Distribution

Table 2 Clinical Symptoms of Patients with Rotavirus Diarrhea

\begin{tabular}{lccc}
\hline \multicolumn{1}{c}{ Variables } & $\begin{array}{c}\text { Patients with RV (+) } \\
\mathbf{N = 8 7 ( \% )}\end{array}$ & $\begin{array}{c}\text { Patients with RV (-) } \\
\mathbf{N = 9 7 ( \% )}\end{array}$ & P value \\
\hline Fever & $17(20)$ & $14(14)$ & NS \\
Vomit & $53(61)$ & $40(41)$ & $<0.05$ \\
Diarrhea only & $30(34)$ & $52(54)$ & $<0.05$ \\
Mucous stool & $25(29)$ & $28(51)$ & NS \\
Bloody stool & $0(0)$ & $4(4)$ & NS \\
Dehydration & & & \\
No & $15(17)$ & $35(36)$ & $<0.05$ \\
Mild/moderate & $53(61)$ & $44(46)$ & $<0.05$ \\
Severe & $19(22)$ & $17(18)$ & $<0.05$ \\
\hline
\end{tabular}

Table 3 Rotavirus Strains Isolated from Children $<5$ Years Old with Diarrhea Addmitted to Hasan Sadikin Hospital January 2006 to March 2007

\begin{tabular}{cc}
\hline Strain & No. $(\%)$ of children $(\mathbf{n}=\mathbf{4 0})$ \\
\hline G-type & $15(37.5)$ \\
1 & $7(17.5)$ \\
2 & 0 \\
3 & 0 \\
4 & $10(25)$ \\
9 & $2(5)$ \\
Mixed infection & $6(15)$ \\
Untype & \\
P-type & $5(12.5)$ \\
4 & $21(52.5)$ \\
6 & $1(2.5)$ \\
8 & $4(10)$ \\
Mixed infection & $9(22.5)$ \\
Untype &
\end{tabular}

\section{Discussions}

This study identified that the prevalence of rotavirus diarrhea in children with acute diarrhea less than 5 years old in Hasan Sadikin Hospital, Bandung from January 2006 to March 2007 was $47 \%$. This finding is similar to those of previous studies, such as Nguyen et $a l^{7}$ in Vietnam (46.7\%) Fauquier et $a l^{8}$ in Spain (31\%), Fang et $a l^{9}$ in China (41\%). In Indonesia also similar to those conducted by Noerdjatmiko et al ${ }^{10}$ in Surabaya (25.3\%), Suharyono ${ }^{11}$ in Jakarta (30.4\%), and Alfa et al ${ }^{12}$ in Bandung $(57.4 \%)$.

We found that prevalence of rotavirus diarrhea 
was highest in infants 6-11 months of age group $(40 \%)$. This agreed with the findings of Cardoso $e t$ $a l^{13}$ in Brazil (31\%) and Chen et al ${ }^{14}$ in Taiwan $(35,4 \%)$. The previous studies in Indonesia such as Noerdjatmiko et al ${ }^{10}$ in Surabaya (32\%) and Subagyo et $a l^{15}$ in Surakarta (31\%) also showed similar results. The high prevalence of rotavirus diarrhea in infants 6-12 months old due to decrease of maternal antibodies and the beginning of oral phase in which food supplementation could increase the risk of rotavirus infection. Table 1 shows that rotavirus infection seems to decrease in children 13-24 months of age. This is similar to others studies, who found that rotavirus infection disease in older children. ${ }^{7,910}$ Thus, infants less than 6 months of age, the low prevalence of rotavirus infection might be due to protection from maternal antibodies. ${ }^{16}$

In our study, males were more affected with rotavirus infection (56\%), which was similar to results of previous studies that concluded rotavirus infection were more commonly found in males who had acute diarrhea. ${ }^{7.13,15}$

Several studies failed to identify seasonal feature in rotavirus infection. ${ }^{6-9.13}$ Some of them evaluate the association between the prevalence of climate and temperature with rotavirus infection, but it seems will need to be reassessed because limited data showed that association. ${ }^{13}$

No distinct seasonal patterns were apparent for rotavirus diarrhea in this study. In poor developing tropical countries, the rotavirus circulates year round, whereas, in developed countries in temperate climates, rotavirus infection is highly seasonal, with little circulation of the virus throughout the rest of the year. ${ }^{17}$

Table 2 shows us that dehydration and vomiting were chief complaints in acute diarrhea patients. Giaquinto et al ${ }^{18}$ found similar result in 150 patients with diarrhea. In their study, the prevalence of dehydration $71.4 \%$ and vomiting $76.7 \%$. Suharyono ${ }^{11}$ in Jakarta reported the prevalence of vomiting was $79 \%$ and Satoto Brotowasisto ${ }^{19}$ also in Jakarta found $75.6 \%$.

In this study, the most common clinical manifestation in children acute rotavirus diarrhea was vomiting. Nguyen et $a l^{7}$ reported the prevalence of vomiting and dehydration was $57.6 \%$ and $50.1 \%$ in children less than 5 years of age with positive rotavirus. Until now, the cause of vomiting in acute rotavirus infection still unclear. Dehydration happened as the compli- cation of vomiting and severe diarrhea. ${ }^{17}$ From literature studies we knew that clinical manifestation of rotavirus infection were less severe in recurrent infection because there was antibodies from previous rotavirus infection. ${ }^{16}$

The most common G-genotype of rotavirus causing diarrhea in children under 5 years of age in this study was G[1 ](37.5\% of strains). The study of Bishop et $\mathrm{al}^{20}$ using monoclonal antibody found that the dominant strains of rotavirus was $\mathrm{G} 3$, with G1 was represented the lowest percentage (1.6\%).

The present study has several limitations. First, in laboratory examination, we did not test for all pathogens but only for rotavirus. So the results only provided us with data on rotavirus but have left us without an etiology of others pathogen. Second, our hospital represents the highest referral in West Java and may not properly reflect admissions to smaller hospitals. It is possible that children with uncomplicated but severe diarrhea are admitted less often to Hasan Sadikin Hospital. This source of bias could well be evaluated in future studies by including a selection of smaller local hospitals.

In conclusions, the prevalence of rotavirus diarrhea in children with acute diarrhea less than 5 years of age in Hasan Sadikin Hospital, Bandung from January 2006 to March 2007 was 47\%. Dehydration and vomiting are higher in patients with rotavirus diarrhea than that with nonrotavirus diarrhea. G1 and P6 are the most common genotype of rotavirus.

\section{Acknowledgment}

The authors would like to thank Indonesian Rotavirus Surveillance Network.

\section{References}

1. Kosek M, Bern C, Guerrant R. The global burden of diarrhoeal disease, as estimated from studied published between 1992 and 2000. Bull WHO. 2003;81(3):197-204.

2. Danovaro MC, Wood AL, LeBaron CW. Rotavirus vaccine and the news media. JAMA. 2002 March 20;207(11):1455-62.

3. Health profile of Indonesia. Jakarta: $\mathrm{MOH} ; 2005$.

4. Child Survival and Health Care in developing countries of Asia. East-West Center: Population and Health Studies; 2003.

5. Sutoto, Indriyono. Strategi dan kebijaksanaan operasional pemberantasan disentri dalam program pemberantasan penyakit diare. Jakarta: Jen. PPM 
\& PLP, Departemen Kesehatan; 1996.

6. Soeparto P. Etiologic factors of persistent diarrhea in developing countries. Folia Medica Indonesiana. 1997 July-September; XXXIII:2937.

7. Nguyen TV, Van PL, Huy CL, Weintraub A. Diarrhea caused by rotavirus in children less than 5 years of age in Hanoi, Vietnam. J Clin Microbiol. 2004;42(12): 5745-50.

8. Fauquier AS, Wilhelmi I, Colomina J, Cubero E, Roman E. Diversity of group A human rotavirus types circulating over a 4-year period in Madrid, Spain. J Clin Microbiol. 2004;42(4):1609-13.

9. Fang ZY, Yang H, Qi J, Zhang J, Sun LW, Tang JY. Diversity of rotavirus strains among children with acute diarrhea in China: 1998-2000 surveillance study. J Clin Microbiol. 2002;40(5):1875-8.

10. Noerdjatmiko, Lintang, Soebijanto, Like SD. Gambaran bakteriologi clan virus pada anak dengan infantile gastroenteritis. In: Ismail R, Pardede N, Rosman, eds. Kumpulan makalah pertemuan ilmiah berkala IX. Palembang: BKGAI; 1984. p. 307-10.

11. Suharyono. Gastroenteritis akut karena rotavirus. ETEC dan Campylobacter. Kongres Nasional Mikrobiologi III, Jakarta 1981.

12. Alfa Y, Mahyudin H, Sudjito, Wahyu H, Donhuijsen W. Prevalensi rotavirus pada tinja anak yang menderita diare akut di RS Hasan Sadikin, Bandung. In: Ismail R, Pardede N, Rosman, eds. Kumpulan makalah pertemuan ilmiah berkala IX. Palembang; BKGAI; 1984. p. 399-402.

13. Cardoso D, Soares CMA, Souza MB, Azevedo M, Martins RMB, Queiroz DA, et al. Epidemiological features of rotavirus infection in Goiania, Goias, Brazil, from 1986 to 2000. Mem Inst Oswaldo Cruz. 2003;98:25-9.

14. Chen SM, Ni YH, Chen HL, Chang MH. Microbial etiology of acute gastroenteritis in hospitalized children in Taiwan. J Formos Med Assoc. 2006 Dec;105(12):964-70.

15. Subagyo, lskandar, Yulidar, Syahrir, Sabdowaluyo. Gambaran enterobakteria dan rotavirus penderita diare akut anak balita di 4 kecamatan, Kabupaten Karang Anyar, Surakarta. In: Ismail R, Pardede N, Rosman, eds. Kumpulan makalah pertemuan ilmiah berkala IX. Palembang: BKGAI; 1984. p. 460-3.

16. Hart CA, Cunliffe NA, Bresee JS. Diarrhoea caused by viruses. In: Cook GC, Zumia Al, eds. Manson's tropical disease. $21^{\text {st }}$ Ed. Edinburgh: WB. Saunders Company; 2003. p. 823-30.

17. Ramig RF. Pathogenesis of Intestinal and Systemic Rotavirus Infection. J Virol. 2004;78(19):1021320.

18. Giaquinto C,Van Damme P, Huet F, Gothefors L, Maxwell M, Todd P, et al. Clinical consequences of rotavirus acute gastroenteritis in Europe, 20042005: the Reveal Study. JID. 2007: 195(Suppl 1): 526-36.

19. Satoto, Brotowasisto. Gambaran klinik dan epidemiologik diare rotavirus di Jakarta. P.I.B VIII, BKGAI. Semarang, 1982.

20. Bishop RF, Unicomb LF, Soenarto Y, Suwardji H, Ristanto, Barnes GL. Rotavirus serotypes causing acute diarrhoea in hospitalized children in Yogyakarta, Indonesia during 1978-1979. Arch Virol. 1989;107:207-13. 